in Great Britain, and why the functions of the Improvement Councils could not be carried out by the Agricultural Research Council and the Technical Development Committee of the Ministry. The report, however, indicates the useful work already performed by the Improvement Councils, and considers that they will play a very useful part in aiding research and putting results into practice.

The report also deals with the institutions and organizations carrying out research, such as the research institutes, some of which are under the direct control of the Ministry of Agriculture, and others of the Agricultural Research Council; the university and advisory departments also play an important part in agricultural research, and their roles are described.

The summary of investigations has been classified on a subject basis ; the work of a particular institute may thus appear in more than one section of the report. This does not, however, detract. from the usefulness of the report or its convenience, because many institutes have been formed to carry out research on a particular crop or subject. As is to be expected, the work in progress has been greatly influenced by war needs, much fundamental long-term work having been suspended in order to secure information necessary for the immediate food production campaign." The Chemistry Department at Rothamsted, for example, now devotes much attention to the estimation of national fertilizer requirements and to the development of efficient methods for allocating fertilizers at varying levels of imports and supplies. Experiments are also in progress there to test new sources of phosphates, town refuse as manure, the value of salt as a substitute for potash, etc. An example of large-scale war-time work is provided by the work of the advisory departments in carrying out the large number of soil tests for lime and phosphate in order to ensure that these important fertilizers reach the soils most in need of them; in 1942 more than 113,000 tests were carried out. These tests aid research because of the value of their results in the mapping of soils. As a contrast to the types of investigation mentioned above may be quoted problems of a more limited nature such as the investigation of the control of weeds in onion crops by chemical methods, in order to reduce the heavy labour involved in the hand weeding of the crop.

There are many investigations described in the report which, though they are of a long-term nature, will yield results of value in the present food production campaign. The grassland investigations in progress at the Welsh Plant Breeding Station, Aberystwyth, and at the Grassland Improvement Station, Dodwell, will result in the gaining of knowledge and experience, which will help to establish sound systems of ley farming under various soil conditions after the War. These investigations, however, have already yielded results which assist ley farming, with its system of restorative crops; this helps in the all-important problem of keeping the land fertile and clean under war-time cropping.

The importance of milk in the national diet of to-day adds interest to the investigations in progress on the yield, nutritive value and keeping qualities of this product. These are carried out at the National Institute for Research in Dairying at Reading, the Hannah Research Institute, Ayr, and at the provincial advisory centres. The effects of certain diseases, such as mastitis, on milk are also being studied. The investigation on mastitis in relation to dairying forms part of a larger programme of research planned and co-ordinated by the Agricultural $R e$ search Council, a section of which is undertaken at the Council's field station at Compton. Investigations on other diseases of dairy cows, forming part of the programmes of work at various animal health research centres, also have an important bearing on the milk situation.

Mention should be made of the co-operation between the Agricultural Research Council, the Department of Scientific and Industrial Research and the Medical Research Council. The three organizations have been created to promote and co-ordinate scientific research on all problems affecting the life and activity of the nation as a whole. It can be readily understood that the relations between these organizations should be very close, since agriculture touches the processing and storage of agricultural products on one hand and medicine or public health on the other. The report illustrates the close relations existing between these three bodies, and summarizes some of the problems that are under investigation by the last two, and that are at the same time of. interest to the Agricultural Research Council.

The extensive field of research work covered by the various organizations has been dealt with in an effective manner, and the classification is clear. The only defect is that referred to in the report itself; namely, that there is little indication as to the relative weight of the attacks on each of the problems listed. As explained in the report, this is difficult, if not impossible, to accomplish in view of war-time conditions regarding shortage of staff, etc.

\section{AMERICAN INSTITUTE OF PHYSICS}

A SURVEY of the first ten years of the work of A the American Institute of Physics has been, presented in a ten-page "Report to Physicists" (Rev. Sci. Inst., 13, 471; 1942). The tendency with the growth of physics is for different groups to "split up' and form a large number of separate societies. The American Institute was planned rather to promote co-operation. A joint committee representing the American Physical, Optical, Acoustical and Rheological Societies recommended that an American Institute of Physies should be founded "to provide a medium to combine their strength for common objectives, to study the publication problem, to obtain financial support and to halt the dispersive trend of physics". The Institute was formally founded in 1931 .

A penetrating analysis of the cost of publication of scientific journals led to a proposal to combine current journals into a single large journal of physics with specialist subdivisions. Practically, however, this left out of account the established tradition and names of the journals, and disregarded the 'society' pride and sense of responsibility with which they were endowed. The proposed change was too drastic to entrust to a new untested organization. As a compromise, the separate journals were brought into a single routine of publication without any change of sponsorship. Unlike the Institute of Physics in Great Britain, it has no individual members and collects no subscriptions in the usual sense. It is a non-profit, educational corporation, the only mem. bers of which are the five founder societies, each as 
an entity. The American Association of Physics Teachers forms the fifth member. The Publications Department issues eight periodicals, the Physical Review, Reviews of Modern Physics, Journal of the Optical Society of America, Journal of the Acoustical Society of America, American Journal of Physics (formerly the American Physics Teacher), Review of Scientific Instruments, Journal of Applied Physics (formerly Physics) and the Journal of Chemical Physics. In 1941, 6,834 pages were published containing approximately 52 million type characters, each of which was checked three or more times by the Institute publication staff.

The Institute has succeoded in obtaining muchneeded new funds for publishing and other services helpful to physicists. During the ten-year period from 1932 to 1941 , about 350,000 dollars of 'new' income was obtained in addition to about 450,000 dollars collected by the Societies as members' subscriptions. Associates of the Institute pay each a subscription of 175 dollars per year. The associate membership in 1942 consisted of twenty-six wellknown industrial organizations.

Attention is directed to the necessity of advertising physics. "Physics is a human activity and, like all others, depends upon the interest with which people in general regard it. In the long run, solid achievement is the best road to general recognition, but even achievement can be overlooked, taken for granted, forgotten through familiarity, or credited to the wrong agent. Unless physicists and their friends occasionally take positive steps to demonstrate and call attention to the advances and services of physics, public attention will readily be diverted to fields which are better displayed and more repeatedly praised." Several readable books about physies and its applications have been written and published at the instigation of the Institute as part of its education and publicity plan. A number of successful symposia have been arranged to present the capacities of physics to well-selected audiences. Noteworthy is the conference on biophysics held in Philadelphia in November 1937, which was attended by some eight hundred biologists, medical men, chemists and physicists, providing a valuable excursion into a borderline subject. This conference was expertly reported by the newspapers. The Institute sponsors such symposia to direct the attention of the public and its industrial and educational leaders to physics by showing its advances and their applications. With the world of business the Institute has established an advantageous connexion for physics and research in general through the National Association of Manufacturers. Encouragement has also been given to the Research Advisory Service extended by a number of banks in various eities to their customers. By these means, industrialists hear an advocacy of research from other industrialists and from bankers "often to be better persuaded than when they hear such a message from research men themselves!"

The War has brought many new problems in which the Institute has been able to act as an established central organization. As to the future, much attention has been given to the training and opportunities for service of the future physicist. The report forms an impressive account of ten years outstanding achievements in physics and in service to the community. The founders of the Institute were concerned with a growing tendency for physics to 'split up'. This same tendeney unfortunately extends to many other human activities. The War is, however, already bringing into closer contact British and American physicists. Developments of transport are shortening time-distances so much that the end of the next ten years may well see a single international Institute of Physics, into which all the separate Institutes have merged as a section of a World Institute of Science.

W. H. G.

\section{FORTHCOMING EVENTS}

(Meetings marked with an asterisk are open to the public)

\section{Monday, April 5} ROXAL GEOGRAPHICAL SocIETY (at Kensington Gore, London,
S.W.7), at 5 p.m.-Miss Marjorie Sweeting: "Wave Trough ExperiS.W.7), at 5 p.m. - Miss
ments on Beach Profiles".

Tuesday, April 6

Chadwick PUbuid LeCTURe (at the Royal Sanitary Institute, 90 Buckingham Palace Road, London, S.W.1), at 2.30 p.m.-Mr. Thomas Sharp: "Town Planning and Public Health"."

ROYal INSTITUTION (at 21 Albemarle Street, Piccadilly, London, W.1), at 3 p.m.- Sir Henry Dale, G.B.E., P.R.S.: "Chemistry in

INSTITUTE OF PHYSICS (ELECTRONICS GROUP) (in the Royal Institution, 21 Albemarle Street, Piccadilly, London, W.1), at 6 p.m. Dr. J. H. Fremlin:" "Physics and the Static Characteristics of Fard vacuum Valves",

\section{Wednesday, April 7}

RoYal Societr of ARTS (at John Adam Street, Adelphi, London, W.C.2), at 1.45 p.m.-Major R. G. Proby: "Agriculture To-day and To-morrow", 8: "Methods and Results of Land Reclamation in

INSTITUTION OF ELECTRICAL ENGINEERS (WIRELESS SECTION) (at Savoy Place, Victoria Embankment, London, W.C.2), at 5.30 p.m.-."

\section{Friday, April 9}

Physical Societry (in the Physics Department, Imperial College of Science, Imperial Institute Road, South Kensington, London, S.W.7), at 4.30, p.m.-Dr, C. R. Burch: "A Technologist Looks at the (Duddell Medal Lecture).

RoYal Astronomical Society (at Burlington House, Piccadilly, London, W.1), at 4.30 p.m.-Annual General Meeting. Prof. S'. Chapman, F.R.S.: "Magnetism in the Sun's Atmosphere" (Presidential Address).

ROYal INSTitution (at 21 Albemarle Street, Piccadilly, London, W.1), at 5 p.m.-Air Commodore Geoffrey Keynes: "The History of Blood Transfusion".

\section{Saturday, April 10}

ASSOCIATION OF UNIVERSTTY PrOFESSORS AND LeCTURERS OF THE ALLIED COUNTRIES IN GREAT BRITAIN (at the Royal Institution, 21 Albemarle Street, Piccadilly, London, w:1)-Educational Conference. At 10 a.m.- "The Function of a University in a Modern Community" Universities in the Future".

\section{Saturday, April 10-Sunday, April II}

INSTITUTe OF PUBLIC ADMINISTRation (JOINT MEETTNG WITH THE INSTITUTE OF INDUSTRIAL ADMINISTRATION AND THE METROPOLITAN AREA EDUCATTON COMMITTEE OF THE NATIONAL ASSOCIATION OF LOCAL GOVERNMENT OFFICRRS) (in the County Hall, Westminster, London, S.E.1).-Conference on "Post-entry Training for Administration-the Need for an Administrative Staff College".

Saturday, Aprii 10

2.30 p.m.-Discussion to be opened by Mr. E. S. Byng.

Sunday, April II

10.30 a.m. -Discussion to be opened by Prof. Harold J. Laski.

Thursday, April 8-Monday, April 12

British Psyohological Society (at St. Hilda's College, Oxford).Extended General Meeting.

\section{APPOINTMENTS VACANT}

Applications are invited for the following appointments on or efore the dates mentioned:

HFAD OF THE BUILDING DEPARTMENT AND LeCTURER IN CIVII ENGINEERING-The Registrar, The Technical College, Sunderland (April 12).

GaS ENGINeer AND Manager-The Town Clerk, Town Clerk's Office, Municipal Buildings, Library Street, Wigan (Ápril 14).

Research Assistant-The Secretary, Animal Diseases Research Association, Moredun Institute, Gilmertion, Midlothian (April 26).

PsYchologist (WOMAN) at the Harrow Child Guidance ClinicThe Clerk to the County Council, "R.2", Middlesex Guildhall, Westminster, London, S.W.1.

SCIENCE GRADUATE, capable of abstracting foreign articles on tech nical horticulture into correct English-The Deputy Director, Imperial Bureau of Horticulture and Plantation Crops, East Malling Research Station, Maidstone, Kent. 